\section{NEW ZEALAND EARTHQUAKES DURING 1940}

$\mathrm{A}^{\mathrm{N}}$ $\mathrm{N}$ interesting and informative account of New Zealand earthquakes and seismology during 1940 is given in Bull. No. R-26, of the Dominion Observatory, Wellington, published in the annual report of the Department of Scientific and Industrial Research, 1940-41 (New Zealand).

Data for the study of earthquakes are obtained locally in New Zealand from instrumental records of three main types and from personal experiences às follows : (1) from teleseismic instruments of varying sensitivity installed at Arapuni, Wellington, Christchurch and Chatham Islands ; (2) from local strongmotion recorders, mostly Jagger seismographs, installed at Rotorua, Hastings, Bunnythorpe, Takaka, Greymouth and Monowai ; (3) from sensitive local recorders of Wood-Anderson design situated at Tuai, New Plymouth, Wellington and Christchurch; (4) from reports of felt earthquakes from non-instrumental reporting stations established with the cooperation of the Post and Telegraph Department.

Periodical reports of felt earthquakes are also received from Dr. C. E. Fox in the Solomon Islands, and also from the Kermedecs. During 1940, 90 earthquakes were reported felt in the North Island, 40 in the South Island, 10 in both islands and 120 over the whole of New Zealand. In the North Island, maximum numbers were in March, July and August, in South Island in February, and in the whole of New Zealand in July.

The ten most important earthquakes occurred : (1) January 12 at $00 \mathrm{~h}$. 05.4m. N.Z.M.T., with maximum intensity 5 on the Rossi-Forel scale, felt extensively from Hawera to Akaroa, with maximum at Wanganui and Blenheim; (2) February 26 at 17h. $46 \cdot 6 \mathrm{~m}$. with intensity between 6 and 7 , felt throughout Hawke's Bay, with maximum at Hastings ; also felt at Taihape and Wanganui ; (3) March 20 at $02 \mathrm{~h}$. $23 \cdot 5 \mathrm{~m}$. with intensity 7 , felt in most eastern districts of North Island as far south as Dannevirke, with maximum in North Hawke's Bay; also felt in parts of Wanganui and Manawatu districts ; (4) April 19 at $18 \mathrm{~h} .11 \cdot 5 \mathrm{~m}$. with intensity 6 , felt widely in North Island south of Napier, Taihape and Hawera, with maximum at Dannevirke (possibly two shocks) ; (5) July 10 at $05 \mathrm{~h} .28 \cdot 1 \mathrm{~m}$. with intensity 6 , felt at Whakatane; (6) July 23 at $01 \mathrm{~h} .01 \cdot 5 \mathrm{~m}$. with intensity 4, felt in western areas of North Island from New Plymouth to Wellington, and at isolated points in northern part of South Island ; (7) August 2 at $04 \mathrm{~h} .28 \cdot 8 \mathrm{~m}$. with intensity 6 , felt in Gisborne region and parts of northern Hawke's Bay ; (8) August 2 at $04 \mathrm{~h} .37 \cdot 4 \mathrm{~m}$. with intensity 6 , felt in Gisborne and parts of northern Hawke's Bay; (9) October 7 at $12 \mathrm{~h}$. $55 \cdot 65 \mathrm{~m}$. with intensity between 6 and 7, felt widely in North Island, except Auckland Peninsula; also at isolated places in South Island to Banks Peninsula; maximum in region between Opotiki and Hawke's Bay; (10) October 22 at $06 \mathrm{~h}$. $16.9 \mathrm{~m}$. with intensity 6 , felt about Cook Strait.

From all the available information it will be seen that the main features of the activity may be summarized as: (1) Two strong shocks centred in the Gisborne coastal regions on August 2. (2) Fairly continuous activity beneath the volcanic zone extending from near White Island to the region south-west of Lake Taupo from March onwards, with a particularly strong shock on October 7. This shock had a focal depth of 160-170 km. and was widely felt. Shocks at intervals centred in the Taumarunui region are considered to be part of the activity connected with the volcanic zone. (3) Activity in Hawke's Bay region reached a climax with the shock on March 20. It was followed by a swarm of minor aftershocks recorded at Tuai, most of which were too weak to be felt. Following this disturbance there was a steady decline in the intensity and frequency of the shocks, and between August and the end of the year only one shock was definitely located in Hawke's Bay. (4) Occasional minor activity centred in north-eastern Taranaki, probably associated with the shocks in the Taumarunui region. (5) Fairly frequent slight or moderate shocks in the WanganuiRangitikei region, many of which were centred in the Wanganui Bight. (6) Rather frequent shocks in the Wairarapa, Wellington, Marlborough and West Nelson regions during the latter half of the year, none of which exceeded Rossi-Forel 5. The coincidence of renewed activity in all these regions about June points to some common cause affecting shock activity in the whole area. (7) Activity in the submarine region east and north-east of the North Island in July-August, and again from October to December.

During 1940, tests were carried out near Greymouth and at Monowai with Milne-Shaw and Wood. Anderson seismographs. Both places were found unsuitable for the Milne-Shaw but suitable for the Wood-Anderson. The co-operation of the Public Works Department has been sought with the view of establishing a Wood-Anderson near Greymouth. Tilt recording has been carried on continuously at Wellington with the aid of the Ishimoto tiltometer and the Milne-Shaw seismograph. The Lands and Survey Department has furnished information on levels taken across geological faults at various points in the Wellington District during the period 1930-40. A study of these level readings, together with seismic data, indicates that certain level changes may have been associated with definite seismic disturbances, though more frequent level readings will be required to confirm this. Since 1936, systematic observations of the north and south meridian marks have been made with the transit instrument. Relative horizontal movements of any one of these points would be revealed by the observations. No appreciable displacements have so far been detected.

\section{CHEMICAL ASPECTS OF TUBERCULOSIS}

$\mathrm{D}^{\mathrm{n}}$ R. FLORENCE B. SEIBERT, associate professor of physiological chemistry at the Henry Phipps Institute, Philadelphia, read a paper during the fiftieth anniversary celebrations at the University of Chicago in September last describing the results of recent chemical studies of the bacillus of tuberculosis.

Dr. Seibert stated that it is now possible to separate the polysaccharides and nucleic acid from the protein of the bacillus, and this has led to the discovery that there are several types of proteins derived from the tubercle bacillus, varying in potency. She also posed the new problem of whether the 'fast component', one of the tuberculin protein types, may be related to an unidentified 'extra' component in the blood serum of persons sensitized to tuberculosis. 